\title{
Explanation of Chinese Piano Music National Character in the First Half of the 20th Century
}

\author{
Ling Qi \\ Hubei Engineering University \\ hunter2011@foxmail.com
}

Keywords: Piano music, National character; Stylize; Music national nationalization

\begin{abstract}
The first half of the 20th century is a period of blending of Chinese and Western cultures, and Chinese piano culture was brought in as a cultural phenomenon in that period. Chinese musicians absorbed Chinese and Western cultures and digested them sufficiently, thereby establishing a set of piano music cultural system with Chinese characteristics. This paper discusses characteristics of Chinese piano music national character in the first half of the 20th century so as to explain cultural connotation of Chinese piano music.
\end{abstract}

\section{Introduction}

Piano music culture almost entered China with the gunfire of Western powers. When advanced weapons changed Chinese national destiny, piano culture penetrated into Chinese culture and took root as a cultural phenomenon. Then, it spread to classrooms from Western religion. While those new blood with full patriotism abided by the idea of "learning from the advanced technologies in the West in order to resist the invasion of the Western powers", so they absorbed Western science, culture, music and so on eagerly, hoping to find a way to save China. Under this general background, piano music was accepted and popularized by traditional culture after the labor pains of blending. Through the endeavors of several generations of artists, piano culture has already formed Chinese styles. This paper explains the national character of the development of piano culture in the first half of the 20th century.

\section{Development history of Chinese piano culture}

Western industrial revolution brought in scientific progress; in the meantime, culture received rapid development. The seclusion policy of the late Qing government led to economic backwardness. In order to obtain more capital and raw materials during development, Western countries used ruthless gunfire to open the gateway of China and plundered properties. While when Western advanced scientific weapons grinded Chinese stuffy cold weapons, Western region and culture were also brought in China, took root and had fruits. Under this general background, domestic politicians, scholars and people from various circles realized the survival principle of "Backwardness will lead to defeat". Under the half force of invaders, people with lofty ideals held the ideals of saving the country, absorbed, accepted and assimilated all kinds of knowledge, hoping to equip their minds with knowledge quickly and driving the invaders away. Piano music culture was established and developed by Chinese people during this wave.

At the beginning of the 20th century, the introduction and development of piano culture all centered on traditional culture. However, because of the influences of politics, economy and culture at that time, development of Chinese piano culture was restrained. Though music talents such as Li Shutong, Liu Tianhua, Li Jinhui and so on emerged, piano music works during this period were mostly under the influences of Western culture. This period is the enlightenment period of Chinese piano music development, including the first Chinese piano music created by Zhao Yuanren- - He Ping Jin Xing Qu. The composer wanted to express his anxiety for political social situation at that time and wish for peace, and he adopted the artistic form of piano. Piano music in enlightenment period was created in the form of "copinism" and did not embody Chinese elements. However, through their propagation and accumulation, they provided large quantities of basis for later 
development. After 1920, piano was available to students from wealthy families or schools. Music exchange meetings, music seminars, music classes all had pretty images of piano music. The abundant music activities ushered in rapid development period for piano music, and creation number and playing techniques became more and more abundant. Chinese musicians always held the ideal of saving the country but did not want Chinese culture to be replaced by Western culture, so they began to integrate piano music with Chinese style. The most representative artists are He Lvting and Liu Xuean. Mu Tong Duan Di of the former and Zhong Guo Zu Qu of the latter were both sensational masterpieces at that time. In the meantime, they showed to the world that Chinese people could express Chinese culture through pianos. However, to the 1930s, during the development in 30 years, piano music culture showed rich Chinese style, which is national character that we explain here and it is the artistic creation philosophy that music pioneers always adhered to and conveyed to countrymen from beginning to end.

\section{Formation of piano music Chinese style system}

Major clue of piano cultural development in the first half of the 20th century is the transition of the style of national character. It can be said that the whole process of piano culture from introduction is the process of chinization. From the probing, hiding and blending of traditional culture at the beginning to Chinese style from inside to outside, this is the process of transforming piano culture. Elements in this process that influence its transformation schedule are various, such as influences of political and economic environment as well as cultural thoughts, understanding of piano culture from musicians who were working at the frontline of cultural transformation and so on. These elements made piano culture at that time present a unique national sense.

Theoretical system of piano music chinization was established in the 1940s. The first available domestic piano research monograph was Gang Qin Ji Ben Tan Zou Fa written by Li Shu Hua in 1941. At that time, Professor Li Shuhua was mainly responsible for piano theories supervisor in State-run Fujian Conservatory. In this book, he explained techniques and skills of piano in detail. At the beginning of theoretical research, there was lots of plagiarism in research results. However, on the basis of plagiarism, musicians summarized, expanded and innovated continuously through their own practices. With the increase of researchers, improvement of researchers' quality and corresponding research achievements were also diffused. To the 1980s, sinicization of Chinese piano music has already formed a set of complete theoretical system.

Research system of piano art during that period was mainly represented in 3 aspects: firstly, it is theoretical research. Artistic creation should have theories as guidance. Only by continuous innovation and perfection and abiding by the rules can national style of piano art be fully represented; secondly, it is the creation of piano music. Representative works at that time were Ou Cheng and Hua Gu, and Hua Gu described people's new life. At that time, Chinese piano music creation took traditional scale and spinning techniques as basis as to melody, and they tended to be national melodies mostly; thirdly, it is performance, i.e., performing art. Chinese traditional music stresses "artistic conception" very much, and "artistic" means inner connotation of music while "conception" means expressing connotation of music. Therefore, regulating the qi flowing in the channels and having the flow during the performance of piano are very important, while at the beginning of Chinese piano art, artists paid much attention to performance of piano and they even assimilated performances of piano and traditional instruments.

\section{Chinese piano music nationalization property}

Usage of grace note. At the beginning of the development of piano music, several grace notes began to be used for assistance. During the continuous perfection of theoretical system, the application of piano music grace notes has become very important creation techniques. Currently, during the teaching of piano in universities, teachers should pay much attention to guidance of grace note creation method. At present, national character of piano music has got represented. Chinese musicians have different opinions on music views and aesthetic philosophy. From the first half of 
the last century, development of piano music began, music pioneers began to distinguish grace notes and themes, and grace notes have their unique performance speed and performance method.

Grace note national character is represented in 3 aspects: (1) Application places are different. Grace notes can appear at any places in Chinese piano music, and it can be the beginning, or the end and even the middle, and can be collocated very flexibly. (2) Application modes are different. National piano music has the difference of short value and long value, the former is composed of two tones and the latter is composed of several tones, and these two elements used Chinese traditional instrument for reference; for example, the performance mode of Guzheng. (3) Properties are different. Grace notes of Chinese piano music have the differences of instrument music and unison rexearch; the former means imitating other types of instrument, while the latter means expressing humans' sounds. Therefore, during classes, teachers should explain differences of Chinese and Western piano music.

Application of tones. One of the influence factors of the charm of music is tones. Changeful tones can endow music stronger impact. At the beginning of the 1940s, Chinese musicians began to try to integrate unique tones of national instrument in piano tones so that national character of piano music strode a landmark step. During the development of Chinese piano music, the most representative work is He Lvting's Mu Tong Duan Di. This work is classic three-section musical form. Especially the performances of the second section, shepherd boy's lively playing needs to be performed. In the meantime, the speed should not be too rapid, and the tones should not be hard and should be clear and melodious as whistling. The work is the first mature piano work in China, and is the turning point and representative work in the development of Chinese piano music.

Application of rhythm. Rhythm supports music. During the performance of Chinese style piano works, characteristics of rhythm should be paid much attention. People believe that rhythms are the bones of works with lively life, and then they are decorated and enriched by other elements. At the beginning of new China, Chinese piano music began to integrate traditional percussion instruments into practices of piano performances. Famous piano music researchers Zhang Boyu believes that bidimensionality represented in the performance gong and drum can be applied in performances of piano. During continuous attempts, composers can use piano to simulate rhythm characteristics of percussion music in the "percussion instruments" in Chinese operas. Just because of the incessant exploration, attempts and innovation of predecessors, Chinese piano forms become more diversified and can integrate the unique rhythm of traditional percussion instruments. Latter, excellent piano works such as Pi Huang, Sheng Dan Jing Mo Chou appeared.

\section{Conclusion}

Music is one of the constituents of human civilization development and different nations have different religions, cultures and art representation forms. Ever since its introduction to China at the beginning of the 20th century, piano has experienced the initial forms to integration of Chinese and Western cultures and then it formed to artistic forms with Chinese national characters. No matter in its creation and performance, we should abide by the connation and values of traditional culture and then develop on the basis of Chinese styles so as to go the world gradually. Contemporary famous composers Du Mingxin warned younger generations that during the creation process of piano works, Characteristics of Huaxia nationality must be integrated; progress of art is the process of continuous communication and study, especially music, it should adhere to the expectations of the new blood during the beginning of piano culture, i.e., renaissance of China. With the gradual rise of our country, mission endowed by history is to realize the prosperity of Chinese nation comprehensively. They should not only be represented in economic abilities and military power, but also culture and art of Chinese nation so that Chines people's cultural viewpoints and national characters can be fully represented, and development of piano music should also go along the path of national characters and stride forward courageously. 


\section{Acknowledgements}

This paper is Hubei province education department humanistic and social science research achievement. Project title: Research of Chinese Piano Music National Character in the First Half of the 20th Century. Project number: 14Q098.

\section{References}

[1] M. Bian. Piano Teaching Should Value Teaching of Modernism Works_-Jiang Wenye’s Piano Devertimento (16 Pieces of Fragment Sketches ); Piano Art; 2001 (3)

[2] J.H. Hao. Cultural Characteristics of Chinese Piano Art in the 1930s and 1940s Under the Influences of Chinese Traditional Culture; Jiangxi Normal University; 2010

[3] Q. Zhan. Research of Piano Concerto Zou Jin Xin Shi Dai and Analysis of Part of His Works; Jiangxi Normal University; 2010

[4] X. Chen. Preliminary Comparison of Creation Development of Violin Music and Piano Music in the First Half of the 20th Century; Yue Fu Xin Sheng (Journal of Shenyang Conservatory of Music); 2005 (04)

[5] X. Chen. Development and Characteristics of Chinese Early Mixture Ensemble Creation__ Taking Piano and Violin Ensemble as An Example [J]; Yue Fu Xin Sheng (Journal of Shenyang Conservatory of Music); 2005 (04)

[6] M.C. Liao. Nationalization Process of Chinese Piano Music_for "China-Africa Music Conversation” in 2005_African Music International Academic Seminar; Music Exploration; 2006 (1)

[7] K. Gong. Development Process and Route of Chinese Piano Music Nationalization; Shen Zhou; $2013(31)$ 